\title{
Geophagic Clayey Materials of Sabga Locality (North West Cameroon): Genesis and Medical Interest
}

\author{
Elvis Duplex Kenne Kalguem ${ }^{1}$, Armand Sylvain Ludovic Wouatong ${ }^{1,}$, , Daniel Njopwouo², \\ Christel Sobdjou Kemteu ${ }^{3}$, Georges Ivo Ekosse ${ }^{4}$ \\ ${ }^{1}$ Department of Earth Sciences, Faculty of Sciences, University of Dschang, Dschang, Cameroon \\ ${ }^{2}$ Department of Inorganic Chemistry, Faculty of Sciences, University of Yaoundé I, Yaoundé, Cameroon \\ ${ }^{3}$ Laboratoire de Traitement Des Minerais, Institut De Recherches Géologiques Et Minières, Yaoundé, Cameroon \\ ${ }^{4}$ Directorate of Research and Innovation, University of Venda, Thohoyandou, South Africa
}

\section{Email address:}

ekennekalguem@yahoo.com (E. D. K. Kenne), aslwouat@yahoo.com (A. S. L. Wouatong),dnjop@yahoo.fr (D. Njopwouo), Sobdjesschrist@yahoo.fr (C. S. Kemteu),ekosseg@gmail.com (G. I. Ekosse)

${ }^{*}$ Corresponding author

\section{To cite this article:}

Elvis Duplex Kenne Kalguem, Armand Sylvain Ludovic Wouatong, Daniel Njopwouo, Christel Sobdjou Kemteu, Georges Ivo Ekosse. Geophagic Clayey Materials of Sabga Locality (North West Cameroon): Genesis and Medical Interest. Earth Sciences. Vol. 8, No. 1, 2019, pp. 45-59. doi: 10.11648/j.earth.20190801.14

Received: January 10, 2019; Accepted: February 14, 2019; Published: March 6, 2019

\begin{abstract}
Geophagia, the deliberate ingestion of clayey materials, is a complex eating behaviour with obscure etiology and numerous health/medical problems. Geological, mineralogical and geochemical studies were carried out on Sabga geophagic clayey materials located within a trachyte Bamenda mountain, about $16 \mathrm{~km}$ east of Bamenda town (North West Cameroon), in order to define the genesis, and its medical interest. Four (04) samples were characterized by different techniques: description of outcrops and pits, particle size distribution by laser dispersion, X-ray diffraction, Fourier transform infrared spectrometry, Scanning electron microscopy and bulk chemical analyses. The main clay minerals were smectite (49-60\%) and kaolinite (4$6 \%$ ). The other major minerals are quartz (19-34\%), feldspar (6-12\%), goethite (3-6\%), and hematite (1-3\%). The average particle diameter varied from 2 to $9 \mu \mathrm{m}$. Results from the different analytical techniques point out a meteoric weathering of feldspar as petrogenetic origin of geophagic clayey materials. Smectite and kaolinite, which are the main desirable minerals components of the geophagic clayey materials, were geochemically derived from surrounding trachytes. However the presence of crystalline silica (quartz) up to $2 \%$ limits the application of some Sabga geophagic clayey materials for pharmaceutical clays. The high radioactive (Th, $\mathrm{U})$, carcinogenic $(\mathrm{Cr}, \mathrm{Cu}, \mathrm{Pb}, \mathrm{Ni})$ and teratogenic (or birth defects) $(\mathrm{Cu}, \mathrm{Zn}, \mathrm{Pb})$ elements contents in some Sabga geophagic clayey materials implied some pretreatment.
\end{abstract}

Keywords: Geophagic Clayey Materials, Meteoric Weathering, Sabga, Trachyte

\section{Introduction}

The consumption of clayey materials occurs in almost all the continents in the world including North America [32], Central America [36], South America [1], Asia [2], Europe [35] and Africa [64, 23, 3, 44]. The practice of consuming geophagic clayey materials is very common in many African countries including Cameroon, where several localities abound in edible geophagic clayey materials. Among the different clay minerals, kaolinite in Koussérie, Mayouom, Dschang and Moko; smectite in Baba and Sabga; and halloysite in Balengou [63, 60, 24, 25, 17, 18, 3, 22, 44] have been reported in Cameroon. As far as pharmaceutical applications of Sabga are concerned, we should keep in mind that fine smectite from Sabga is ingested by neighbouring populations (mainly by pregnant women).

Smectite and kaolin are used in modern pharmaceuticals to prevent nausea, vomiting, and gastrointestinal disorders [96, $18,3,44]$. Geophagia has been of interest to researchers and analysts due to continued habitual, religious and cultural practices by diverse global communities in spite of reports contraindicating its purported benefits. Most geophagic 
clayey materials are highly retentive due to their fine-grained sizes allowing their absorption of metal ions. The concentration levels of these elements determine their usefulness or harmfulness when consumed by humans. Geophagic clayey materials are considered as sources of elemental supplementation especially $\mathrm{Fe}, \mathrm{Ca}, \mathrm{K}$ and $\mathrm{Zn}$, as well as toxic metals such as $\mathrm{As}$ and $\mathrm{Pb}$ [50].

No known studies have been carried out to characterize the Sabga geophagic clayey materials. Thus, neither the genesis nor the suitability of clays for medicinal applications has been carried out. Effective valorisation of monomineral clays such as kaolin, talc, and smectite as raw materials for applications in the pharmaceutical, ceramic, paint, and paper industries among others often needs knowledge of the clay deposit genesis [58, 65] and the mineral quality $[6,56,53]$, and geochemical composition [24]. The mineralogical inertness dictates that the silica polymorphs (quartz) should not exceed 2\% [89], because they have been considered responsible for carcinogenicity [38].

A wide range and variety of minerals are used as excipients in pharmaceutical preparations including oxides (rutile, zincite, periclase, hematite, maghemite, magnetite), hydroxides (goethite), carbonates (calcite, magnesite), sulphates (gypsum, anhydrite), chlorides (halite, sylvite), phosphates (hydroxyapatite), phyllosilicates (smectites, palygorskite, sepiolite, kaolinite and talc) and recently tectosilicates (zeolites) [13]. Within the smectite group, montmorillonite, saponite, and hectorite are the most widely used clay minerals. Smectites can be used as disintegrant, diluent and binder, emulsifying, thickening and anticaking agent, and carrierreleaser in pharmaceutical preparations [13].

The term "bentonite" is too generic, as it can be used both for a rock consisting mainly of smectites (mineralogy) or a material mainly containing montmorillonite (pharmacy).

The focus of this study was therefore to mineralogically and geochemically analyse geophagic clayey materials from Sabga locality in the physical state in which they are ingested, in order to elucidate on the deposit quality, its genesis and possible medicinal utilisation. It is anticipated that the findings of the study could establish baseline mineralogical and geochemical characterizations of Sabga geophagic clayey materials; and contribute to the renewed and recently rekindled research interests [92], and intellectual debates on geophagic practice within the broader scientific community [29, 77].

\section{Geographic and Geological Setting}

Sabga area belongs to the Bamenda Highlands and is sited at latitudes $5.58^{\circ}$ to $6.03^{\circ} \mathrm{N}$ and longitudes $10.19^{\circ}$ to $10.25^{\circ} \mathrm{E}$ (Figures 1c and 2a). This locality is located about $16 \mathrm{~km}$ east of Bamenda town, North West Cameroon. The relief is hilly with an altitude range between 1180 and $2050 \mathrm{~m}$ and separated by $\mathrm{U}$ and $\mathrm{V}$ valleys. The hydrographic network shows dendritic drainage. The climate is Sudanese tropical, with temperatures between 17 and $23^{\circ} \mathrm{C}$; and annual mean rainfall of $2396 \mathrm{~mm}$. This area is also characterised by geothermo and mineral springs [14].

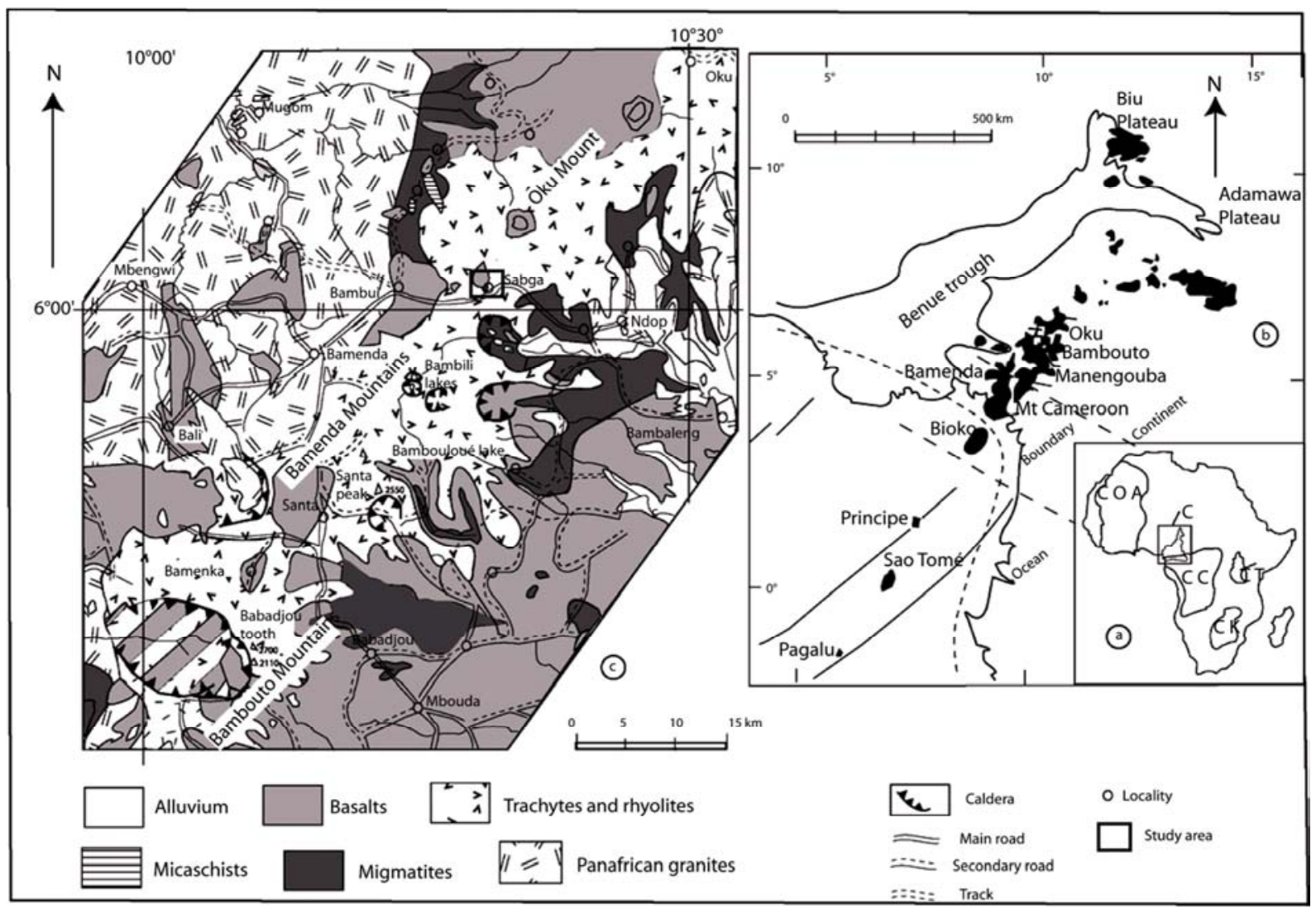

Figure 1. Geological map of the Bamenda Mountains showing the location of study area [42] (a) Location of Cameroon in Africa; (b) location of the Bamenda Mountains along the Cameroon line showin the outcrop of the Cameroon line volcanic rocks (black) (c) Location of the western highlands. $C=$ Cameroon. $C O A=$ West African Craton; $C C=$ Congo Craton; $C T=$ Tanzanian Craton; $C K=$ Kalahari Craton. African Cratons. 
This climate allows the formation of colluvial deposits soils on magmatic and metamorphic basements around the Sabga Mountain. The soils have been studied for potential oil bleaching earth, adsorbents for mercury (II) species, adsorption of lead (II) ions utilized on a commercial scale to decontaminate industrial effluents [82, 45, 47]. Detailed geological, pedological data have not been reported on the studied area.

The area under study is part of the Bamenda Mountains, situated on the Cameroon Volcanic Line (CVL). Sabga locality is located between the Bamboutos Mountains to the South West and the Oku massive to the North West (Figure 1). This volcanic province is made up of both mafic and felsic rocks lying on a Panafrican or older basement [41]. The felsic lavas are mainly represented by trachytes, with subordinated benmoreites and alkaline to peralkaline rhyolites [40], whereas the mafic rocks are basalts to mugearites [41]. The area is made up of rock pedestals (plutono-metamorphic) with volcanic rocks and alluvium overlying on top of it. The volcanic rocks formations are made up of trachytes, rhyolites, ignimbrites and basalts [43, 14, 26]. Trachytes appear exclusively at the mountain peaks. The expected parent rock of the geophagic clayey materials is a trachyte which is in the form of slabs and is greenish, massive and encloses laths of feldspar oriented in the same direction as the typical trachytic structure. The rock displays a microporphyritic texture and is composed of pyroxens, feldspar and plagioclase [43]. Trachyte is highly fractured thereby facilitating weathering.

\section{Methods}

\subsection{Field Observation of the Geophagic Clayey Materials}
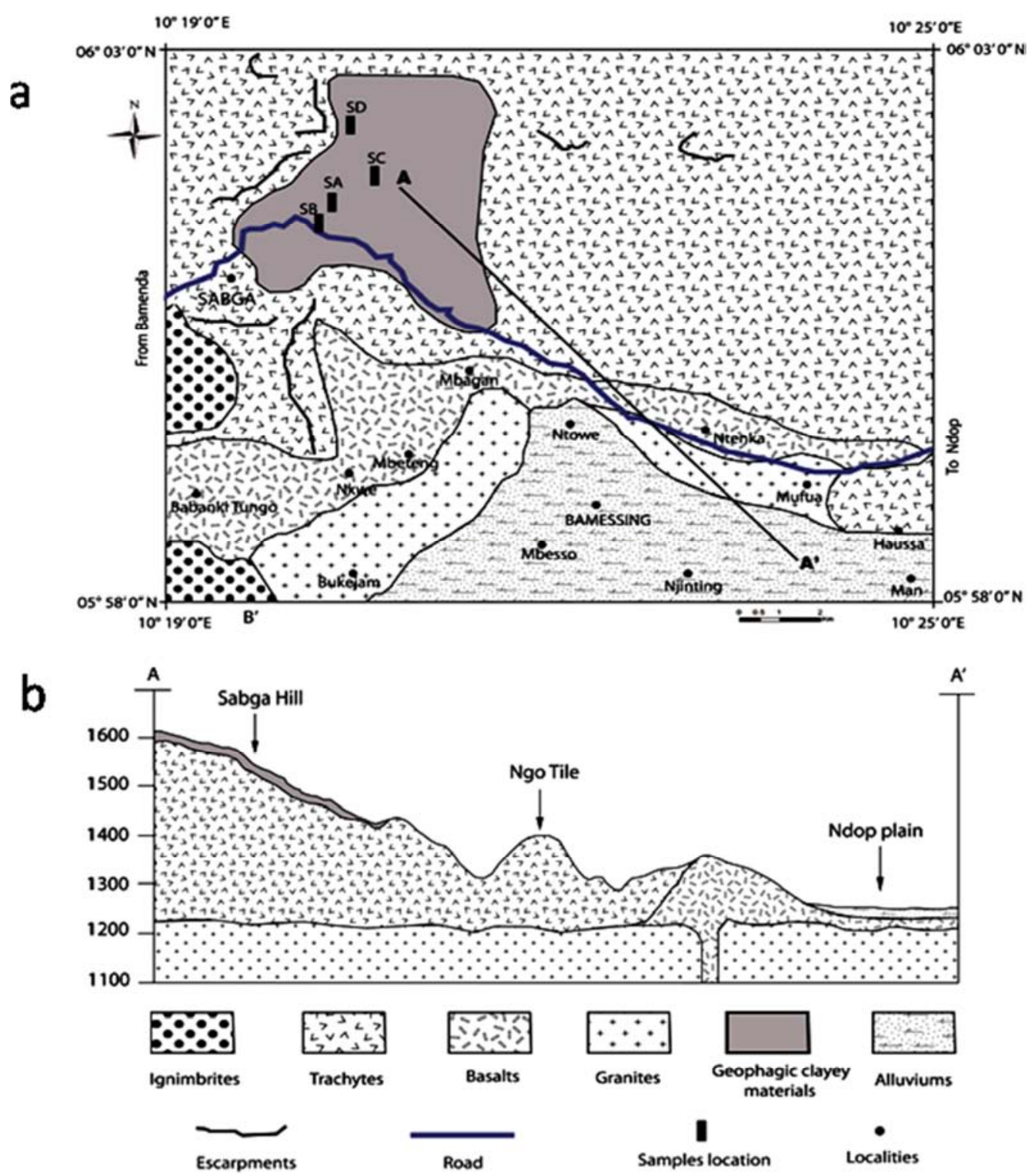

Figure 2. Detail geological map of Sabga geophagic clayey materials (with the location of analysed samples) and related interpretative sketch cross section $\left(A-A^{\prime}\right.$. 
The gangue constituted by organo-mineral and lateritic soil layers. A detail geological map after the field mapping is shown on Figure 2a. Cross section illustrates the structure of the geophagic clayey materials (Figure $2 b$ ). The whole soil section shows 5 successive layers. From the top to bottom, they include: An brown organic matter-rich A horizon (0-0.1 $\mathrm{m})$ with a sandy loam texture and crumb structure; a thick B horizon made up of a lateritic surface and mottled subsurface composed of a 0.1-0.5 m thick, reddish brown (7.5R4/6), and reddish yellow (7.5 YR 6/8), with clayey sand, gravels and abundant quartz grains. The transition to the saprolite below is not gradual. A weathered $\mathrm{C}$ horizon is constituted of three layers, with very thick $(0.5-3.5 \mathrm{~m})$. Saprolite is represented by these three layers. The first layer is grey whitish $(2,5 \mathrm{Y}$ $8 / 1$ ), compact with a $0.5-2 \mathrm{~m}$ thick and clayey texture. The second layer is yellow (10YR 7/8) mixed with grey and white patches, with clayey texture and a 2-2.5 m thick. The third layer is whitish grey $(2,5 \mathrm{Y} 8 / 1)$, very compact with clayey sand texture and a 2.5-3.5 m thick, spotted with yellow nodules with many slighty weathered fragments of trachyte. At mid-way of the Sabga hill formed by trachyte, the geophagic clayey materials outcrops in small interfluves, thus constituting nest of ore easily identified by the white, grey yellow and red soil. They outcrop on the Sabga hill some eight $\mathrm{km}$ from different escarpments. The representative vertical cross section presents from the top to the base (Figure 3).

\subsection{Sampling and Samples}

On the Sabga clay deposit mine, four pits of varying depths of 4 to $10 \mathrm{~m}$ were dug. Samples of geophagic clayey materials commonly ingested by individuals in Sabga locality were obtained from different sites. The samples were the true representatives of the different geophagic clayey materials available in Sabga locality. Four geophagic clayey material samples (SA, SB, SC, SD) were collected for laboratory analyses (Figure 2).
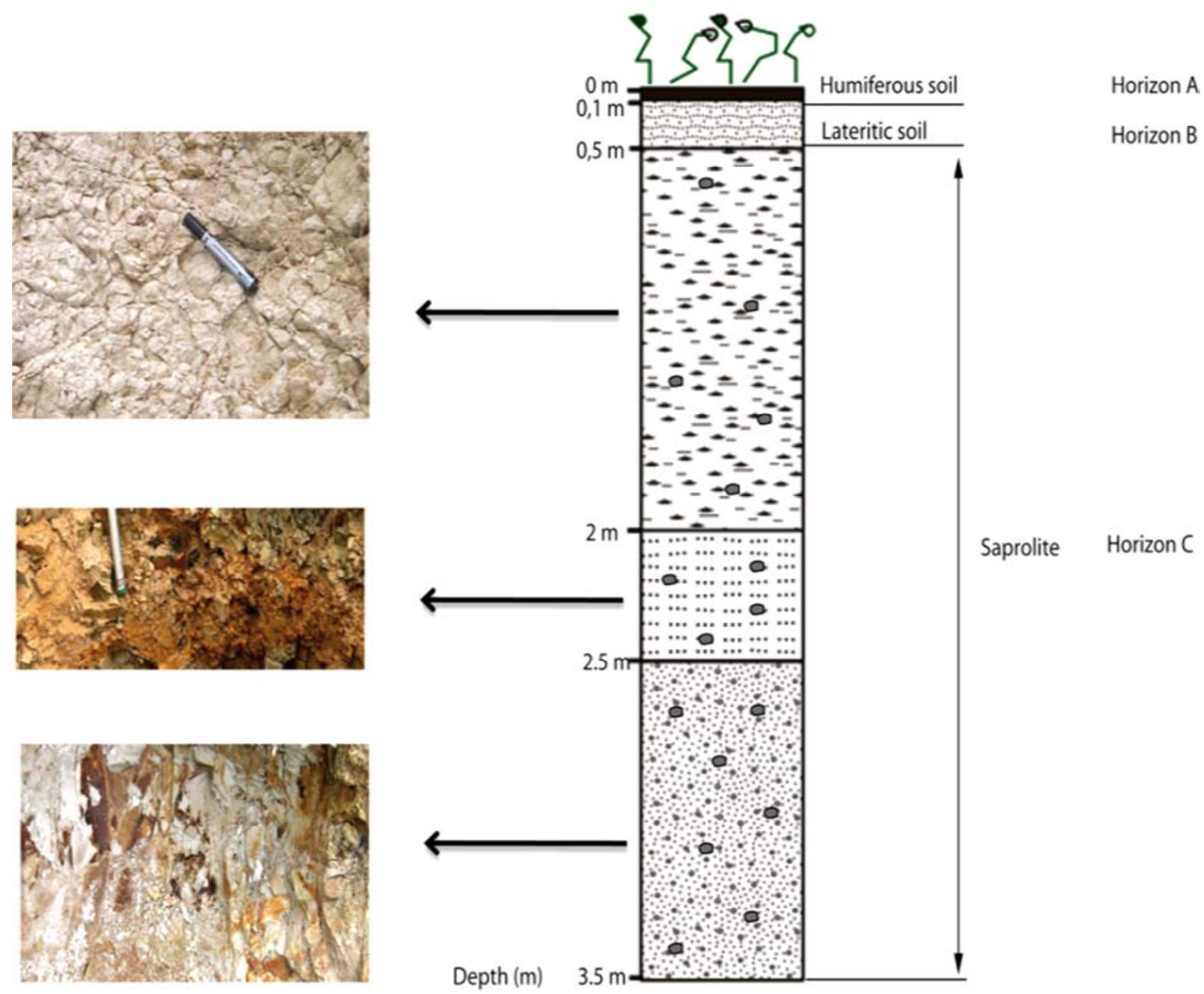

Figure 3. Vertical profile of top to base horizons of the Sagba Outcrop.

\subsection{Laboratory Analyses}

Laboratory analyses conducted included particle size distribution by laser dispersion, X-ray diffraction (XRD), Fourier transform infrared (FTIR) spectroscopy, scanning electron microscopy (SEM) and major and trace elements 
compositions analyses.

Particle size distribution of the geophagic clayey materials was determined by laser light scattering using a Malvern Masteriser 2000 particle size analyzer at the Laboratory of "Chimie" University of Liège in Belgium. A suspension of each sample was then loaded into a Malvern Mastersizer 2000 fitted with a Hydro 2000G dispersion unit. A polydisperse mode of analysis and a refractive index of 1.53 with an adsorption of 0.1 were chosen. Size data collection was performed at constant obscuration in the range $10-20 \%$. Scattered light data were recorded from 2000 to 5000 snapshots of $10 \mu \mathrm{s}$. The correlation between the angles of light scattered from the particles in a laser beam was used to determine the size distribution of these particles. Particle data generated for each soil sample included the PSD and derived diameters D10, D50 and D90, where D10, D50 and D90 represent the 10th percentile, median diameter and $90^{\text {th }}$ percentiles respectively of the geophagic clayey material samples. Values for D10 and D90 describe the maximum particle diameter below which $10 \%$ and $90 \%$ respectively of each sample volume exist.

Mineralogical analysis were carried out at the Laboratory of "Argiles, Géochimie et Environments Sédimentaires", University of Liege (AGEs, Belgium). X-ray diffraction patterns were done with a Bruker Advance D8 diffractometer using a $\mathrm{Cu}-\mathrm{K} \alpha$ radiation under $40 \mathrm{kV}$ and $30 \mathrm{~mA}$ operating conditions. Bulk powder was studied following normal procedure of clay analysis as presented in [57]. The mineral percentages in different samples are calculated using the height of a diagnostic peak multiplied by a corrective factor $[12,8]$ together with the so-called $100 \%$ approach (the term $100 \%$ approach connotes that the sum of all phase quantities identified in a sample is $100 \%$ ). The common reflection of total clays at $4.47 \AA$ is multiplied by a corrective factor of 20 to give an estimate of the total clays in the bulk sample. For the semi-quantification of the different clay minerals and non clay minerals, the estimation of smectite and kaolinite were based on the height of 001 reflections (at $\sim 14$ and $\sim 7 \AA$, respectively) with a correction factor of 0.7 and 0.25 , respectively [27] on glycolated specimens estimation of quartz, feldspar, goethite and hematite were based on the height of 001 reflections $(3.35,3.24,4.97$ and $2.07 \AA$ respectively) with correction factor of $1,4.3,7$ and $\sim 3.33$ respectively $[12,8]$. For clay fractions, three patterns were recorded in sequence under natural condition, after saturation with ethylene-glycol for 22 to $24 \mathrm{~h}$, and heating at $500^{\circ} \mathrm{C}$ for 4 h. Mineral identification was processed using EVA software. Semi-quantitative mineralogical composition of bulk powder was estimated from the intensity of a diagnostic peak multiplied by a corrective factor $[12,8]$. For the clay fraction, semi quantitative estimation was based on the height of specific reflections, generally measured on EG runs [5]. Smectite in natural condition appearing at $14 \AA$ and in the glycolated preparation, gives a very strong (001) reflection at $17 \AA$ [57]. After heating, the smectite peak collapses at $10 \AA$ (Figure $5 \mathrm{a}, \mathrm{b}$ ). Kaolinite is identified by the disappearance spacing around $7 \AA$ on heating (Figure 5b).

Fourier transform infrared spectra were recorded in the 4000 $400 \mathrm{~cm}^{-1}$ range on Bruker FTIR Spectrometer at the Laboratory of "Minéralogie" University of Liège in Belgium, using pressed pellets heated to $110^{\circ} \mathrm{C}$ overnight. The disks of $2 \mathrm{~cm}$ diameter were prepared by mixing $10 \mathrm{mg}$ sample with $150 \mathrm{mg} \mathrm{KBr}$.

The scanning electron microscopy (SEM) was used to observe their morphology and size; the observations were carried out on an ESEM Philips XL-30 device at laboratory of "Chimie Inorganique Structurale" (University of Liege). The images were obtained by a secondary electron detector after metallization with gold powder by plasma spraying for an accelerating voltage scan.

Major elements analyses were performed at the laboratory of "Pétrologie Sédimentaire (PETROSED)" at the University of Liège in Belgium by emission spectrometry using inductively coupled plasma and atomic emission source (ICP-AES). Trace elements and rare earths analyses were performed at the laboratory of Géochimie Environnement de Surface Gestion des Collections, Musée Royale d'Afrique Centrale Bruxelles in Belgium by mass spectrometry (ICPMS) after fusion with $\mathrm{LiBO}_{2}$ and dissolution in $\mathrm{HNO}_{3}$.

\section{Results}

\subsection{Qualitative Mineralogy of Geophagic Clayey Materials}

The main minerals identified by XRD in geophagic clayey materials (Figure 4) are a 14.12 $\AA$ phase considered as 2:1 phyllosilicate group mineral, a $7.18 \AA$ phase assigned to kaolinite and characteristic peaks of feldspar and quartz. The $14.12 \AA$ phase is the predominant mineral in all the samples. Goethite and hematite had weak or few characteristic peaks in some samples.

The SEM micrographs show that geophagic clayey materials are characterized by the presence of pseudospherical smectite aggregates with different shapes and sizes (Figure 6a, b, d). The smectite particles forming the aggregates are less than $10 \mu \mathrm{m}$ in size and they are characterized by corn-flake morphologies (Figure 6b, c).

The FTIR spectra of geophagic clayey materials samples (Figure 7) show the $\mathrm{OH}$-stretching vibrations region (3700 $\left.3400 \mathrm{~cm}^{-1}\right)$. The infrared absorption spectra show a sharp band around $3620 \mathrm{~cm}^{-1}$ due to $\mathrm{OH}$ stretching (Figure 7). This band, clearly visible on Figure $7 \mathrm{~b}, \mathrm{c}, \mathrm{d}$, corresponds to AlAlOH stretching of smectite [48]. The band at $3697 \mathrm{~cm}^{-1}$ (Figure 7b, d) are characteristic of kaolinite [93], and 3620 $\mathrm{cm}^{-1}$ is related to the presence of montmorillonite [49]. The $\mathrm{Si}-\mathrm{O}$ stretching band is observed in the IR spectra of both diand tri-octahedral smectites, montmorillonite at $1030 \mathrm{~cm}^{-1}$ $1035 \mathrm{~cm}^{-1}$. The presence of quartz in all samples is confirmed by $\mathrm{Si}-\mathrm{O}$ symmetrical stretching vibrations around $792 \mathrm{~cm}^{-1}$ and $795 \mathrm{~cm}^{-1}$. The bands at $1637 \mathrm{~cm}^{-1}-1641 \mathrm{~cm}^{-1}$ are due to adsorbed water [33]. 


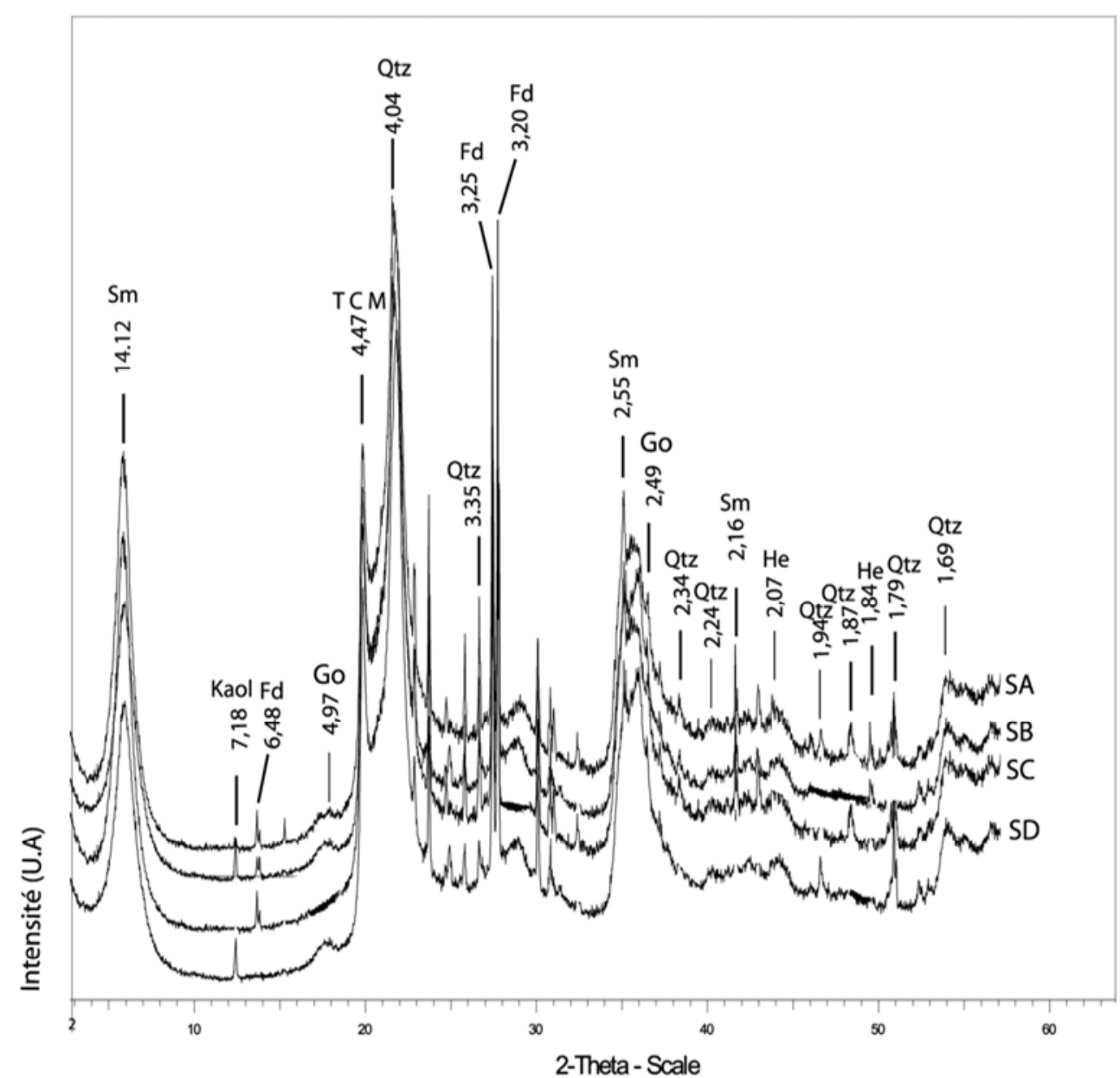

Figure 4. XRD patterns of Bulk powder. Sm = Smectite; Kaol = Kaolinite; $T$ C M = Total Clay Mineral; Fd = Feldspar; Qtz=Quartz; He = Hematite; Go = Goethite.
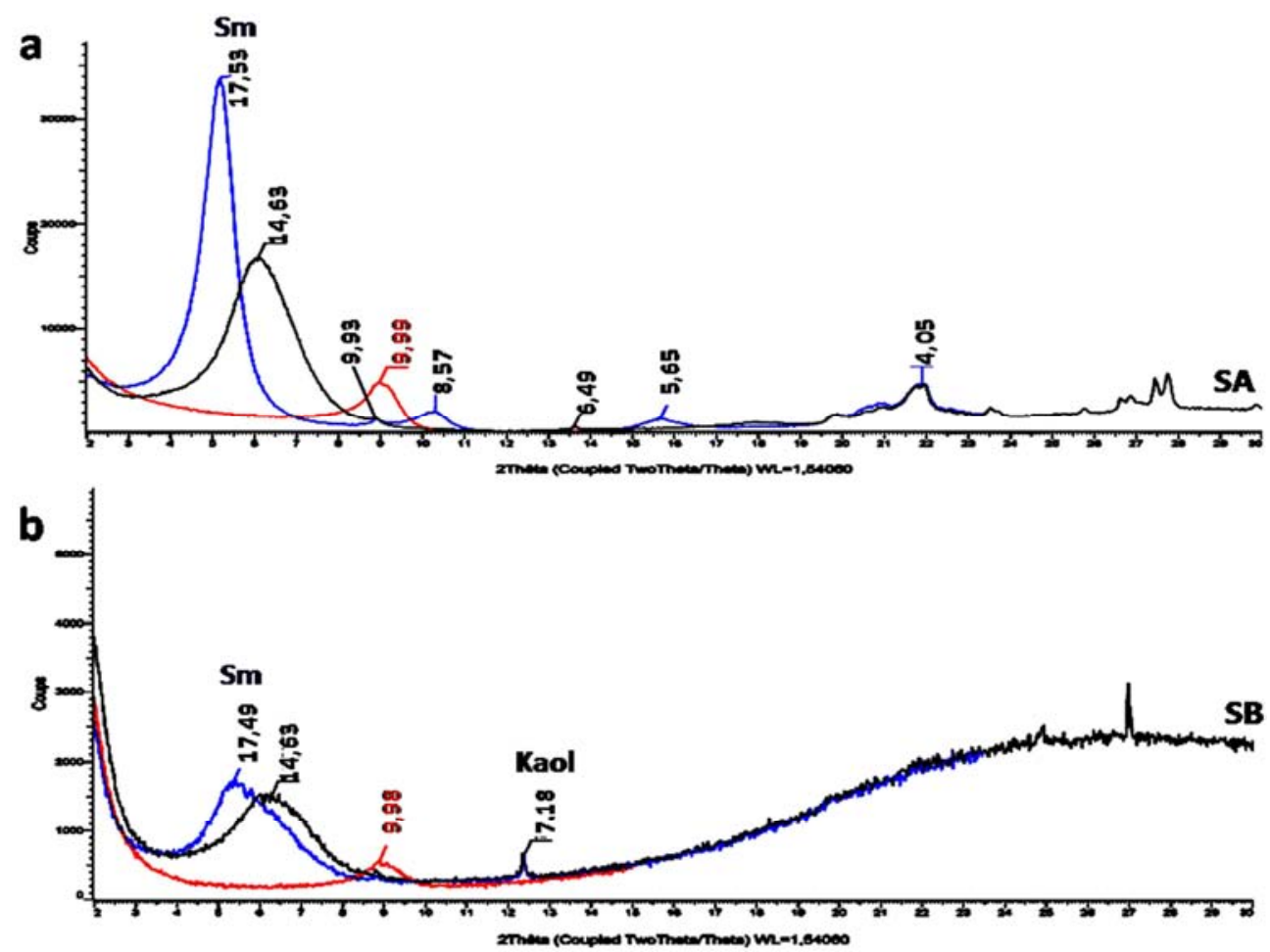

Figure 5. XRD patterns of clay fraction. Black pattern = untreated; Blue pattern = solvated by ethylene glycol; Red pattern $=$ heat-treated at $500^{\circ} \mathrm{C} ; \mathrm{Sm}=$ Smectite $;$ Kaol $=$ Kaolinite. 

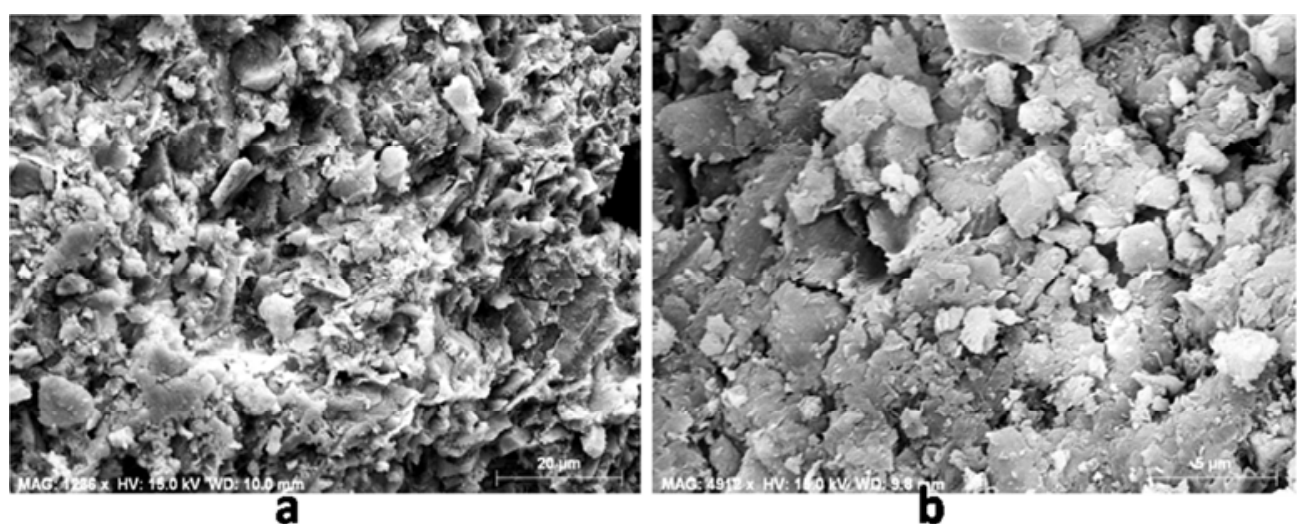

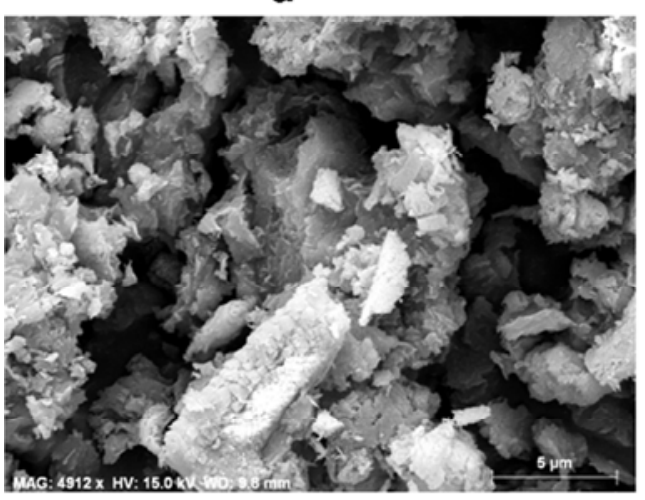

C

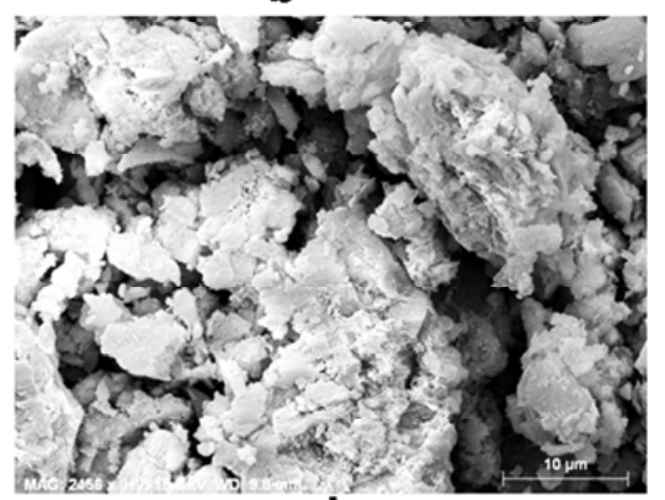

d

Figure 6. Some examples of the smectite micromorphology found in Sabga geophagic clayey material samples. a, b) SEM of sample SA; c, d) SEM of sample $S B$.

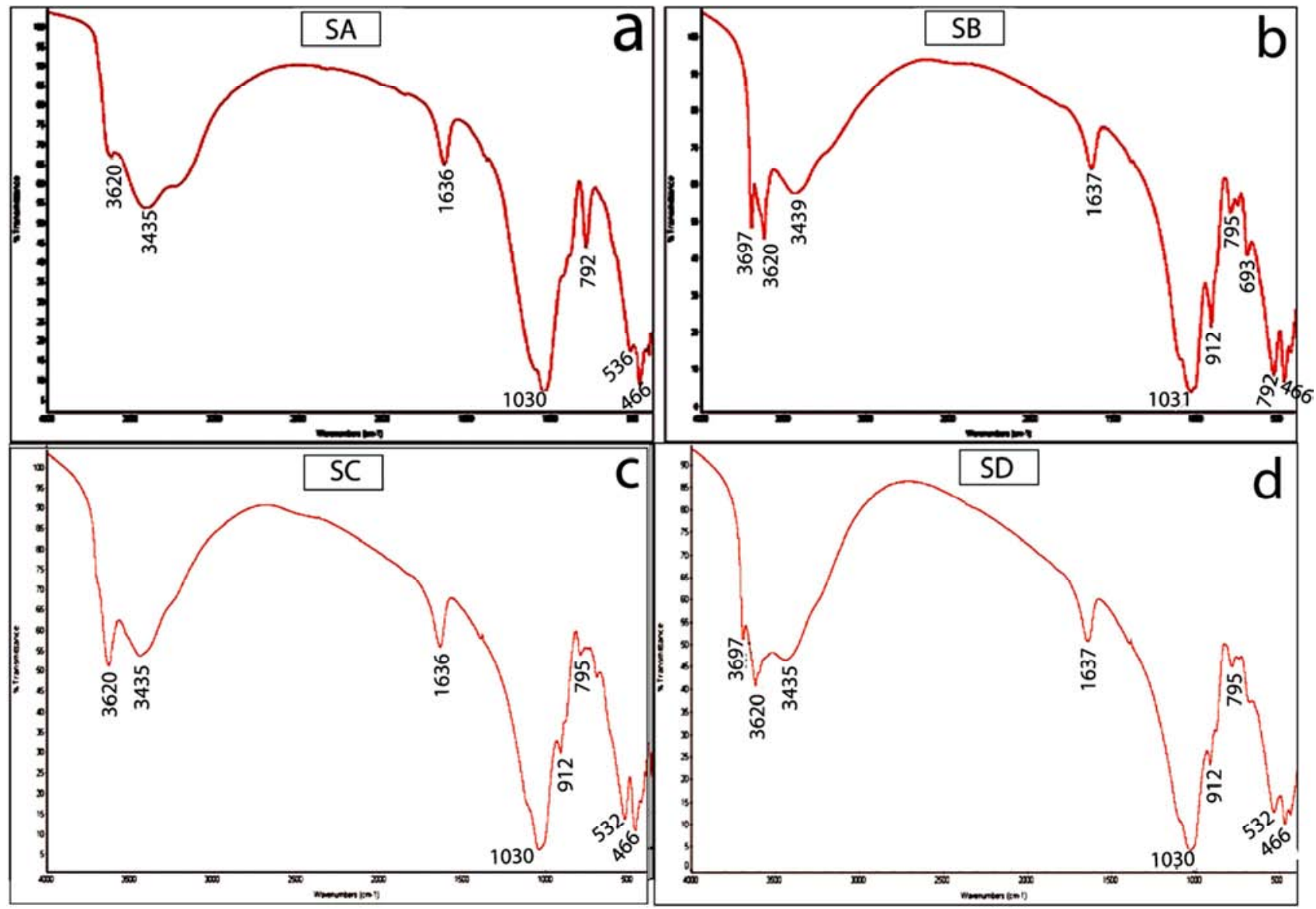

Figure 7. FTIR spectra for geophagic clayey materials from Sabga. 


\subsection{Semi-Quantitative Mineralogy of Geophagic Clayey Materials}

Results of mineralogical reconstitution are shown in Table 1. The samples display high smectite and kaolinite contents, 49-60\% for smectite and 4-6\% for kaolinite. Associated minerals are feldspar 6-12\%, quartz (19-34\%), goethite 3-6\%, and hematite $1-3 \%$.

\subsection{Particle Size Distribution of Geophagic Clayey Materials}

Values for the median diameter of the particles making up the Sabga geophagic clayey materials ranged from $1.8-$ $9.3 \mu \mathrm{m}$, while values of D10 and D90 for of the particles making up the geophagic clayey materials ranged from
0.85-132 $\mu \mathrm{m}$ and $4-60 \mu \mathrm{m}$ respectively (Figure 8). The derived diameters of individual samples are presented in Table 2.

\subsection{Geochemistry of Geophagic Clayey Materials}

\subsubsection{Major Oxides}

All samples had silica content ranging from 41.52-47.89 wt $\%$. These chemical characteristics correlate with quartz content. The alumina $\left(\mathrm{Al}_{2} \mathrm{O}_{3}\right)$ contents in the soils were also slightly higher with a range of 11.03-23.41 wt\% (Table 3). Samples also had very high values for the Fe oxides $(4.42 \%$ in sample SC to $10.62 \%$ in sample SD) (Table 3), inducing yellowish and reddish colour of samples.

Table 1. Mineralogical composition of Sabga geophagic clayey materials (wt.\%) by the method using a corrective factor.

\begin{tabular}{llllllll}
\hline Samples & Smectite (\%) & Kaolinite (\%) & Total Clay Mineral (\%) & Quartz (\%) & Feldspar (\%) & Goethite (\%) & Hematite (\%) \\
\hline SA & 60 & 0 & 60 & 19 & 12 & 6 & 3 \\
SB & 52 & 6 & 58 & 32 & 6 & 3 & 1 \\
SC & 49 & 4 & 53 & 34 & 10 & 4 & 1 \\
SD & 59 & 0 & 59 & 26 & 8 & 4 & 3 \\
\hline
\end{tabular}

Contents of $\mathrm{TiO}_{2}, \mathrm{P}_{2} \mathrm{O}_{5}$, and $\mathrm{MnO}$ were each $<1 \mathrm{wt} \%$, and the alkali and alkali earth metals $\left(\mathrm{K}_{2} \mathrm{O}, \mathrm{Na}_{2} \mathrm{O}, \mathrm{CaO}\right.$ and $\left.\mathrm{MgO}\right)$ were low in wt concentrations (Table 3). Loss on ignition values ranged from $15.52 \mathrm{wt} \%$ in sample $\mathrm{SA}$ to $20.55 \mathrm{wt} \%$ in sample SC (Table 3 ).

The very high $\mathrm{Al}_{2} \mathrm{O}_{3} / \mathrm{MgO}$ (40.7 to 58.8) and very low
$\mathrm{MgO} / \mathrm{Fe}_{2} \mathrm{O}_{3}$ (0.00 to 0.08$)$ ratio in the samples of Sabga geophagic clayey materials analysed confirm the high impurities because $\mathrm{Al}_{2} \mathrm{O}_{3} / \mathrm{MgO}$ ratio of purified bentonite should be between 3.5 and 5.5, while in the purified standard both magnesium and ferric ions are equal in the octahedral layer as the $\mathrm{MgO} / \mathrm{Fe}_{2} \mathrm{O}_{3}$ ratio is equal to one $[81,85,86,87,88]$.

Table 2. Granulometric distribution of geophagic clayey materials.

\begin{tabular}{|c|c|c|c|c|c|c|c|c|}
\hline Samples & $<2 \mu \mathrm{m}(\%)$ & $2-20 \mu \mathrm{m}(\%)$ & $>20 \mu \mathrm{m}(\%)$ & $<63 \mu \mathrm{m}(\%)$ & $\mathrm{D} 10(\mu \mathrm{m})$ & D50 $(\mu \mathrm{m})$ & D90 $(\mu \mathrm{m})$ & $D_{\text {Medium }}(\mu \mathrm{m})$ \\
\hline SA & 53.19 & 46.08 & 53.92 & 100.00 & 0.85 & 1.8 & 4 & 2 \\
\hline SB & 16.67 & 72.24 & 27.76 & 97.19 & 1.5 & 5.5 & 20 & 3 \\
\hline SD & 8.81 & 62.33 & 37.67 & 90.18 & 2 & 9.30 & 60 & 9 \\
\hline
\end{tabular}

\subsubsection{Trace Elements}

For trace elements compositions of studied geophagic clayey materials (Table 3), some trends are present. The concentrations of $\mathrm{Y}, \mathrm{Nd}, \mathrm{Ce}, \mathrm{Nb}, \mathrm{Th}, \mathrm{La}, \mathrm{Zn}$ and $\mathrm{Zr}$ were high (Table 3). As, Cd, Co, Ge, $\mathrm{U}$ and $\mathrm{Ni}$ had the lowest concentrations with all values being $<10 \mathrm{ppm}$ (Table 3 ). The concentrations of other elements $(\mathrm{Cu}, \mathrm{Ga}, \mathrm{Hf}, \mathrm{Pb}, \mathrm{Sc}, \mathrm{Sm}, \mathrm{Ta}$ and $\mathrm{Th}$ ) were between 10 and $75 \mathrm{ppm}$ (Table 3 ).

Trace elements such as $\mathrm{Co}, \mathrm{Cu}$ and $\mathrm{Zn}$ which are of nutritional significance to humans and $\mathrm{Ni}, \mathrm{Pb}$, and $\mathrm{Cr}$ which have lower toxicity thresholds were relatively low compared to those found in soils for agricultural purpose [61]. Attention must be drawn to the amounts of $\mathrm{Pb}$ and As in the pharmacopeia limits for "Bentonite" and "Purified Bentonite". Limits for $\mathrm{Pb}$ are 40 and $15 \mathrm{ppm}$, and for As the limits are 5 and 3 ppm respectively [83, 84]
However, trace element analyses (Table 3) show notable amounts of radioactive $(\mathrm{Th}, \mathrm{U})$, carcinogenic $(\mathrm{Cr}, \mathrm{Cu}, \mathrm{Pb}$, $\mathrm{Ni}$ ) and teratogenic (or birth defects) $(\mathrm{Cd}, \mathrm{Cu}, \mathrm{Zn}, \mathrm{Pb})$ elements, higher than those reported in recommended pharmaceutical clays [51]. The REE content normalized to Sabga trachyte [42] and chondrite CI values of [52] are shown in (Figure 9a, b). The trachyte normalised trace elements patterns for representative geophagic clayey materials from the Sabga locality are parallel and flat with negative $\mathrm{Eu}$ and $\mathrm{Ce}$ anomalies (Figure 9a). The chondrite normalised trace elements patterns for representative geophagic clayey materials from the Sabga locality show similar REE patterns, being more enriched in LREE compared to HREE with distinct negative $\mathrm{Ce}$ and $\mathrm{Eu}$ anomalies (Figure 9b). 
Table 3. Major elements and trace elements compositions of geophagic clayey materials from Sabga compare with a pharmaceutical clay composition (sample named Pharm Clay is from [46] and [51].

\begin{tabular}{|c|c|c|c|c|c|}
\hline Samples & SA & SB & SC & SD & Pharm Clay \\
\hline \multicolumn{6}{|c|}{ Major elements (oxides in wt.\%) } \\
\hline $\mathrm{SiO}_{2}$ & 41.52 & 47.11 & 47.73 & 47.89 & $44.6-46.4$ \\
\hline $\mathrm{Al}_{2} \mathrm{O}_{3}$ & 11.03 & 23.41 & 21.18 & 17.13 & $38.1-39.5$ \\
\hline $\mathrm{Fe}_{2} \mathrm{O}_{3}$ & 4.64 & 7.65 & 4.42 & 10.62 & $0.1-0.2$ \\
\hline $\mathrm{MnO}$ & 0.12 & 0.01 & 0.11 & 0.12 & - \\
\hline $\mathrm{MgO}$ & 0.21 & 0.00 & 0.36 & 0.42 & $0.1-0.2$ \\
\hline $\mathrm{CaO}$ & 0.34 & 0.15 & 0.56 & 0.79 & $0.1-0.2$ \\
\hline $\mathrm{Na}_{2} \mathrm{O}$ & 0.33 & 0.10 & 0.77 & 0.33 & $0-0.1$ \\
\hline $\mathrm{K}_{2} \mathrm{O}$ & 1.22 & 0.75 & 1.56 & 1.42 & $0-0.2$ \\
\hline $\mathrm{TiO}_{2}$ & 0.27 & 0.74 & 0.29 & 0.67 & $0-1.4$ \\
\hline $\mathrm{P}_{2} \mathrm{O}_{5}$ & 0.07 & 0.05 & 0.03 & 0.03 & - \\
\hline L. O. I & 15.52 & 19.60 & 20.55 & 20.35 & $13.8-13.9$ \\
\hline Total & 94.59 & 99.20 & 98.55 & 98.97 & - \\
\hline $\mathrm{Al}_{2} \mathrm{O}_{3} / \mathrm{MgO}$ & 52.52 & 0.00 & 58.8 & 40.7 & - \\
\hline $\mathrm{MgO} / \mathrm{Fe}_{2} \mathrm{O}_{3}$ & 0.04 & 0.00 & 0.08 & 0.04 & - \\
\hline \multicolumn{6}{|c|}{ Trace elements (ppm) } \\
\hline As & $<\mathrm{dl}$ & $<\mathrm{dl}$ & $<\mathrm{dl}$ & $<\mathrm{dl}$ & $<0.3$ \\
\hline $\mathrm{Sc}$ & 11.8 & 10.4 & 13.8 & 12.5 & 10.2 \\
\hline V & 4.7 & 2.6 & 2.6 & 1.0 & 24 \\
\hline $\mathrm{Cr}$ & 7.0 & 1.9 & 3.1 & 3.5 & 5.4 \\
\hline Co & 1.3 & 0.9 & 0.8 & 2.1 & 5 \\
\hline $\mathrm{Cd}$ & $<\mathrm{dl}$ & $<\mathrm{dl}$ & $<\mathrm{dl}$ & $<\mathrm{dl}$ & 0.02 \\
\hline $\mathrm{Ni}$ & 7.5 & 4.2 & 3.1 & 4.3 & 5 \\
\hline $\mathrm{Cu}$ & 18.7 & 23 & 39 & 63 & 4.71 \\
\hline $\mathrm{Zn}$ & 248 & 147 & 177 & 989 & 9 \\
\hline $\mathrm{Ga}$ & 48 & 69 & 42 & 84 & 1.79 \\
\hline $\mathrm{Ge}$ & 4.4 & 3.8 & 1.4 & 3.0 & n.d \\
\hline $\mathrm{Rb}$ & 82 & 14.5 & 10.0 & 56 & 83 \\
\hline $\mathrm{Sr}$ & 48 & 11.4 & 39 & 55 & 100 \\
\hline Y & 123 & 137 & 132 & 200 & 29 \\
\hline $\mathrm{Zr}$ & 927 & 1648 & 624 & 3114 & 162 \\
\hline $\mathrm{Nb}$ & 151 & 260 & 101 & 520 & n.d \\
\hline Cs & 4.8 & 2.1 & 1.00 & 3.8 & - \\
\hline $\mathrm{Ba}$ & 76 & 46 & 108 & 98 & 147 \\
\hline $\mathrm{Bi}$ & $<\mathrm{dl}$ & $<\mathrm{dl}$ & $<\mathrm{dl}$ & $<\mathrm{dl}$ & 0.16 \\
\hline $\mathrm{La}$ & 122 & 249 & 277 & 459 & 25.8 \\
\hline $\mathrm{Ce}$ & 169 & 242 & 120 & 540 & 46 \\
\hline $\operatorname{Pr}$ & 27 & 66 & 67 & 115 & n.d \\
\hline $\mathrm{Nd}$ & 99 & 241 & 241 & 403 & 19 \\
\hline $\mathrm{Sm}$ & 18.8 & 45 & 41 & 69 & 4.7 \\
\hline $\mathrm{Eu}$ & 1.07 & 4.6 & 2.4 & 3.5 & 0.8 \\
\hline $\mathrm{Gd}$ & 18.7 & 34 & 32 & 49 & n.d \\
\hline $\mathrm{Tb}$ & 1.72 & 2.19 & 1.56 & 2.08 & 0.7 \\
\hline Dy & 19.5 & 26 & 24 & 36 & n.d \\
\hline Но & 3.9 & 4.6 & 4.3 & 6.3 & n.d \\
\hline $\mathrm{Er}$ & 11.1 & 12.1 & 11.2 & 17.6 & n.d \\
\hline $\mathrm{Tm}$ & 0.38 & 0.80 & 0.91 & 0.55 & n.d \\
\hline $\mathrm{Yb}$ & 9.4 & 9.5 & 8.9 & 14.8 & 2.4 \\
\hline $\mathrm{Lu}$ & 1.36 & 1.38 & 1.30 & 2.1 & 0.4 \\
\hline Hf & 23 & 32 & 15.5 & 66 & 4.3 \\
\hline $\mathrm{Ta}$ & 10.4 & 18.0 & 7.7 & 36 & 0.9 \\
\hline W & 4.4 & 6.7 & 1.3 & 2.8 & $<1$ \\
\hline $\mathrm{Pb}$ & 37 & 15.0 & 15.5 & 67 & 6.5 \\
\hline Th & 30 & 45 & 28 & 89 & 8.8 \\
\hline $\mathrm{Hg}$ & $<\mathrm{dl}$ & $<\mathrm{dl}$ & $<\mathrm{dl}$ & $<\mathrm{dl}$ & 0.0 \\
\hline $\mathrm{U}$ & 8.0 & 7.6 & 1.98 & 9.2 & 2.1 \\
\hline
\end{tabular}

LOI = Loss of ignition (wt.\%); $<\mathrm{dl}=<$ to detection limits; $\mathrm{n} . \mathrm{d}=$ not determined; 


\section{Discussions}

\subsection{Genesis of the Studied Geophagic Clayey Materials}

Sabga geophagic clayey materials outcrop within trachyte. Determining the origin of geophagic clayey materials (meteoric weathering or hydrothermal alteration) for pharmaceutical use is essential because the suitability of a clay deposit as pharmaceutical excipient greatly depends on its geological nature (sedimentary, residual, and hydrothermal) and mineral composition of the deposits, which have an important effect on texture and particle size distribution, and consequently, on the rheological properties (flow) of the powder mass [59, 31]. It is relatively easy to establish an hydrothermal origin of high temperature facies, with potassic alteration for example [37]. As the temperature of transformation decreases, there is a great resemblance between meteoric and hydrothermal minerals. The assemblages can have the following phases in common: smectite, vermiculite, kaolinite and illite. However, the geological setting, field characteristics of the deposit, associated minerals and geochemical signatures allow to distinguish differences between the two alteration phenomena $[54,20,21,65]$. To determine the origin of Sabga geophagic clayey materials, these geological features are taken into account. In Cameroon, where several localities abound in edible clayey material deposits developed during meteoritic alteration of various rocks. Among the different clay minerals, we have friable halloysite deposit resulting from weathering of trachyte and phonolite from Mount Bamenda at Santa, Bali, Bambili and Sabga areas [69], more than $15 \mathrm{~m}$ thick kaolinitic clays at Lembo and Bana, which may have developed during meteoritic alteration of various rocks (granite, rhyolite, trachyte and basalt) of the Bana tertiary ring complex $[94,65]$ and kaolin deposit of Balengou (halloysite) which may have been formed from alteration of trachyte [63].

The geological setting of Sabga area is a volcanic environment, composed of trachyte, rhyolite, basalt and ignimbrite (Figure 2). These rocks have different characteristics as rocks at high temperature and pressure like mylonites. This zoning morphology is characterised by the absence of tectonic structures such as veins, foliation and fault. From the above details, it is suggested that the process of forming geophagic clayey materials is completely different from the typical hydrothermal alteration profile $[10,11,65]$.

With these geological features, the field characteristics are close to those generally reported for meteoric weathering clayey materials. According to various analytical techniques (XRD, FTIR, scanning electron microscopy and chemical analyses), Sabga geophagic clayey materials have the following mineral phases: smectite + kaolinite, + feldspar + quartz \pm goethite \pm hematite. This paragenesis also indicates that the smectite and kaolinite are the alteration product of feldspar.

In humid tropical climate, meteoric weathering generally leads to the formation of kaolinite with poor crystallinity due to numerous impurities as $\mathrm{Fe}, \mathrm{Ti}, \mathrm{Cr}$ and $\mathrm{Ni}$ in kaolinite structure $[71,10,11,65]$. No hydrothermal alteration mineral indicator as florencite, pyrite, chrysotile and lizardite or any ore associated minerals was found in the geophagic clayey materials $[10,11,65,66]$. Sabga geophagic clayey materials contain some amounts of alkalis and alkali earths despite their location on steep slope hills under tropical humid climate. These are good drainage conditions that must have favoured the leaching of these elements during meteoric weathering [80].

Geochemical compositions can give information about the origin of the alteration. From the oxides chemistry, the small $\mathrm{TiO}_{2}$ contents and the high $\mathrm{Fe}_{2} \mathrm{O}_{3}$ contents corroborate with meteoric weathering because meteoric weathering generally enhances the presence of ferric oxides and hydroxides in tropical climate $[54,74,65]$; and $\mathrm{TiO}_{2}$ may be concentrated in anatase by hydrothermal fluids $[58,34]$. Ce anomalies are well known in weathering and lateritic soils formation process.

The studied geophagic clayey materials were compared to the REE composition of Sabga B08 trachyte of [42] and of chondrite CI [52]. In Sabga geophagic clayey materials, negative $\mathrm{Ce}$ and $\mathrm{Eu}$ anomalies have been observed in all patterns (Figure 9a, b). The REE patterns are parallel, suggesting that all the geophagic clayey materials were formed through the same process. Generally, Positive Ce anomalies are well known in weathering and lateritic soils formation process. These anomalies are produced when $\mathrm{Ce}^{3+}$ is oxidized to $\mathrm{Ce}^{4+}$ favoured under an oxidizing environment in the weathering profile $[55,10,11,19,15,67,65]$. Conversely, hydrothermal processes usually occur in more reducing conditions $[20,21]$ where $\mathrm{Eu}^{3+}$ is reduced to $\mathrm{Eu}^{2+}$ and fractionates differently from other REEs. Commonly, the absence of positive and negative $\mathrm{Ce}$ anomaly confirms hydrothermal alteration $[65,79]$. Figure 9 points out $\mathrm{Ce}$ anomalies, as it is the case of supergene smectite and halloysite clay deposit of Lisbonne in Portugal [73], clay minerals of Kombelcha and Bombowha in Ethiopia [28], quartz-rich smectitic clays of the northern part of Cameroon formed in a confined environment under a Sahelian climate [62] and halloysite clay deposit of Balengou [80].

Geophagic clayey materials samples from Sabga display peculiar deep negative $\mathrm{Ce}$ and $\mathrm{Eu}$ anomalies (Figure 9). These anomalies reflect a selective leaching of these two elements during geophagic clayey materials formation processes. The chondrite-normalized REE patterns of the geophagic clayey materials show LREE enrichments and a negative $\mathrm{Eu}$ anomaly (Figure $9 \mathrm{~b}$ ). The HREE patterns are almost slightly flat (Figure 9b). Eu anomaly suggesting that it developed at least partially in response to feldspar weathering, where most of the Eu is hosted [7]. These characteristics are similar to that of clay-rich sediments from central Uganda Makoro derived from granitoid rocks [68]. 


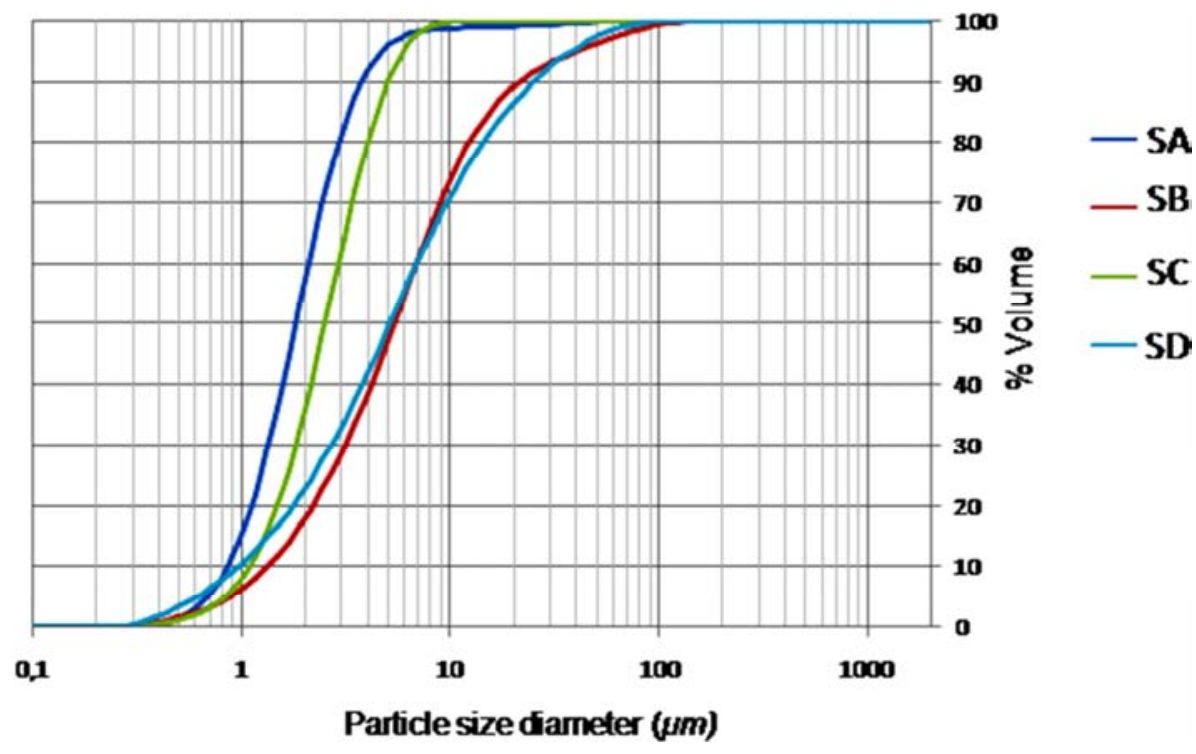

Figure 8. Particle size distribution curve of geophagic clayey materials.
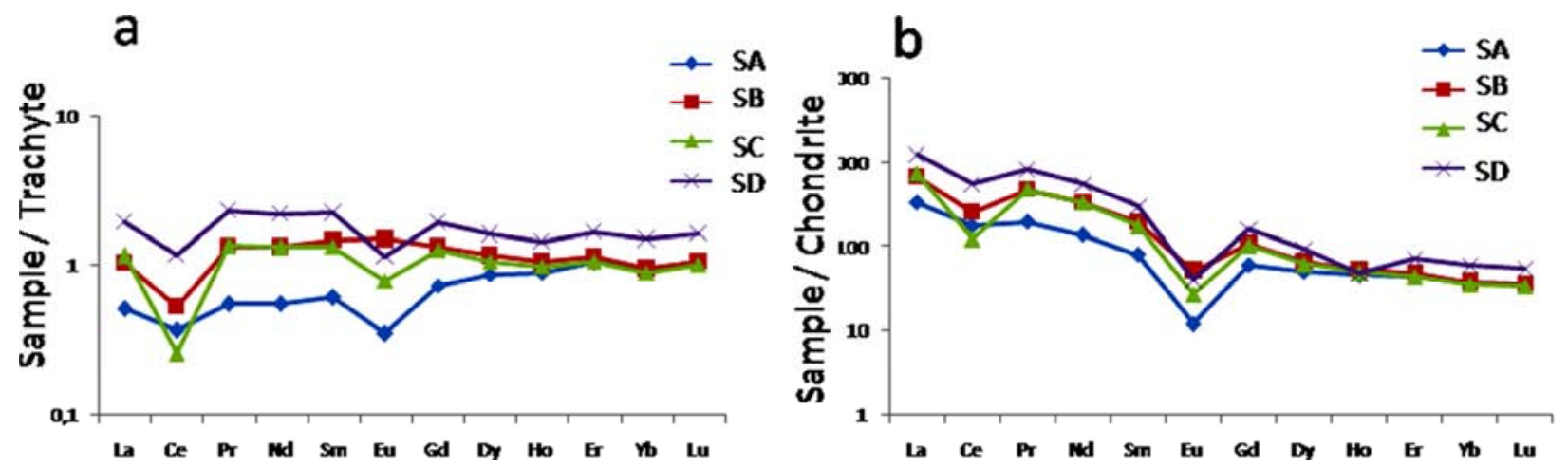

Figure 9. Rare earth elements contents of Sabga geophagic clayey samples normalized to Sabga trachyte B08 [42] and CI chondrite [52].

\subsection{Medical Interest of the Studied Geophagic Clayey Materials}

The geochemical and mineralogical constitutions of these soils are likely to have some implication on the health of the geophagic individuals. Table 3 indicates that the chemical composition range of geophagic clayey materials from Sabga is very similar to that of natural smectite used in pharmacy and cosmetics [46] except for its high $\mathrm{Fe}_{2} \mathrm{O}_{3}$ contents. Sabga geophagic clayey materials have radioactive, carcinogenic and teratogenic (or birth defects) elements, higher than those reported in recommended pharmaceutical clays [51]. Thus from the chemical compositions, the direct ingestion of Sabga geophagic clayey materials may be hazardous. The raw material should be purified before pharmaceutical and cosmetic uses.

Samples SA, SD with relatively higher amounts of smectite, sample SB, SC with a combination of kaolinite and smectite could contribute to the alleviation of gastrointestinal discomfort related to diarrhea and the elimination of toxins in geophagic individuals. According to [30] oxides of Fe would result in different pigment colours in soils including reddish and yellowish colours (Figure 3). Most of the studied samples were reddish and yellowish and hematite and goethite were identified in some of them. This may be attributed to the presence of Fe-bearing mineral (Table 1) and $\mathrm{Fe}$ oxides and hydroxides in the soils (Table 3). Geophagic individuals from Sabga locality indicated that they ingested the soils for famine and pregnancy related reasons. Despite Fe providing supplement for those who lack iron in their blood, a high level of $\mathrm{Fe}$ in the blood could result in hemochromatosis and possible death [91]. Besides, the consumption of Fe-rich lateritic soils may negatively influence the utilisation of copper and zinc in the body [9].

Zinc concentration in the studied Sabga geophagic clayey materials were highest in samples SA, SB, SC, SD with respectively 248, 147, 177 and 989 ppm. Having a recommended value for zinc of $0.01 \mathrm{ppm}$ [91], excessive consumption of these clayey materials may lead to unusual drowsiness, nausea, vomiting, diarrhea and growth retardation of an unborn baby [75]. Zinc plays a vital role in cellular metabolism and is a major component of body tissues and fluids [78]. Most catalytic activities of enzymes require zinc, which is equally required for immune function, wounds healing, protein synthesis, DNA synthesis and cell division. Zinc ions are effective antimicrobial agents even at low concentrations [70]. Zinc is also required for proper functioning of the senses of taste and smell and supports 
normal growth and development during pregnancy, childhood, and adolescence [4]. There are claims of zinc having antioxidant properties, which may protect against accelerated aging and helps speed up the healing process after an injury. However, studies differ as to its effectiveness [70].

Chromium has been reported to be responsible for lung cancer and death [76]. The highest concentration of $\mathrm{Cr}$ was recorded in all samples as shown in Table 3 (1.9-7.0ppm) which is above the World Health Organization recommended value of $0.05 \mathrm{ppm}$ [91]. Sample SD had the highest concentration of $\mathrm{Pb}$ with $67 \mathrm{ppm}, \mathrm{SB}$ and $\mathrm{SC}$ have the lowest concentration of 15.0 and $15.5 \mathrm{ppm}$ respectively. Daily recommended value for lead $(\mathrm{Pb})$ is $0.01 \mathrm{ppm}$ [91]. The presence of $\mathrm{Pb}$ in the samples poses a problem as there is no prescribed limit for its consumption due to its extreme toxic nature. Previous studies revealed that exposure to lead may cause intelligence decline in children and as well as cancer in adults [90]. Consumption of these clayey materials over a long period may result in serious health effects such as coma, seizure, dysfunctioning of the kidney, liver and heart of the consumers.

The particle size diameter of geophagic clayey materials (Table 2) was lower than $10 \mu \mathrm{m}$. The PSD curves for the samples are very close to each other (Figure 8). Knowledge of particle size distribution features of the raw materials is essential for the right pre-formulation steps of cosmetic and pharmaceutical products [39]. Based on the literature [72] the powder particle size distribution applicability can vary. Finer powders have higher skin adhesion and provide better softness when applied on skin. One example showing that particle size influences powder properties is the research published by [72], which demonstrated that products for topical application containing in their composition clay of average particle size around $74 \mu \mathrm{m}$ provided promising results related to augmented blood flow toward the treated skin region. The analyzed clays showed particle size between 2 and $9 \mu \mathrm{m}$. This reduced particle size range suggests the application of clays in cosmetics. According to literature, particles smaller than $63 \mu \mathrm{m}$ may have anti-inflammatory effects and may assist in the skin hydration, retaining moisture due to the high skin adhesiveness [16]. Samples from Sabga had higher mean values of D (90) $4-60 \mu \mathrm{m}$ (Table 2) compared with $8.3-53.8 \mu \mathrm{m}$ for samples of pharmaceutical clays originated from the sand extraction residue of mining activities in the hinterland of São Paulo state, Brazil [39].

\section{Conclusion}

Prospection and characterization studies carried out in the Sabga locality have revealed the presence of heterogeneous geophagic clayey materials along the higher slopes of Sabga hill formed by trachyte. It comprises smectite and kaolinite resulting from the alteration of trachyte. Non-clay mineral assemblages comprise feldspar, quartz, goethite and hematite, pointing out an alteration controlled by oxidizing environment. No hydrothermal alteration mineral indicators are identified in geophagic clayey materials. Trachyte and chondrite normalized trace element patterns for representative geophagic clayey materials show negative $\mathrm{Ce}$ and $\mathrm{Eu}$ anomalies. All these characteristics lead to the interpretation that geophagic clayey materials are from a meteoric weathering origin. From granulometric, mineralogical and chemical properties, geophagic clayey materials can be considered as pharmaceutical clays after some previous treatment to reduce the amount of toxic metals and crystalline silica (quartz). Studies on bioavailability of Fe and $\mathrm{Zn}$ elements in the gastrointestinal tract are however necessary to determine which percentage of the total concentration is actually available for assimilation upon ingestion. Nevertheless, the potential medicinal application of these clayey materials is supported by the smectite and kaolinite contents, and fines particles size. In contrast, the trace elements are pointers of probable adverse effects on humans.

\section{References}

[1] Abrahams, P. W., Parsons, J. A. (1996) Geophagy in the tropics: a literature review. Geogr. J., 162 (1): 63-72.

[2] Aufreiter, S., Hancock, R. G. V., Mahaney, W. C., Stambolic, R. A., Sanmugadas, K. (1997) Geochemistry and Mineralogy of soils eaten by humans. Int J. Food Sci. Nutr., 48 (5): 293305 .

[3] Banenzoue, C. (2017) Argiles consommées par géophagisme au Cameroun: Caractérisation physico-chimique, thermique et propriétés antiacide. Thèse de doc. $3^{\mathrm{e}}$ cycle, Univ. Yaoundé I, $187 \mathrm{p}$.

[4] Bhattacharya, P. T., Misra, S. R., Hussain, M. (2016) "Nutritional Aspects of Essential Trace Elements in Oral Health and Disease: An Extensive Review," Scientifica, vol. 2016.

[5] Biscaye, P. E. (1965) Mineralogy and sedimentation of recent deep-sea clay in the Atlantic Ocean and adjacent seas and oceans. Geological Society of America Bulletin, 76, 803- 832.

[6] Bloodworth, A. J., Highley, D. E., Mitchell, C. J. (1993) Industrial Minerals Laboratory Manuel: KAOLIN. BGS Technical Report WG/93/1. 76 pp.

[7] Bloundi, M K. (2005) Etude géochimique de la lagune de Nador (Maroc oriental): Impacts des facteurs anthropiques. thèse de doctorat en co-tutelle en sciences de la terre et de l'univers. Université Mohamed V- Agdal, p 238.

[8] Boski, T., Pessoa, J., Pedro, P., Thorez, J., Dias, J. M. A., Hall, I. R. (1998) Factors governing abundance of hydrolysable amino acids in the sediments from the N. W. European Continental Margin (47- $\left.50^{\circ} \mathrm{N}\right)$. Progress in Oceanography, 42, 145-164.

[9] Brand, C. E., De Jager, L., Ekosse, G. I. E. (2009) "Possible health effects associated with human geophagic practise: an overview," Medical Technology SA, vol. 23, pp. 11-13.

[10] Braun, J. J., Pagel, M., Muller, J. P., Bilong, P., Michard, A., Guillet, B. (1990) Cerium anomalies in lateritic profiles. Geochim. Cosmochim. Acta 54, 781-795. 
[11] Braun, J. J., Viers, J., Dupré, B., Polve, M., Ndam, J., Muller, J. P. (1997) Solid/liquid REE fractionation in the lateritic system of Goyoum, East Cameroon: the implication for the present dynamics of soil covers of the humid tropical regions. Geochim. Cosmochim. Acta 62 (2), 273-299.

[12] Cook, H. E., Johnson, P. D., Matti, J. C., Zemmels, I. (1975) Methods of Sample Preparation and X ray Diffraction in Xray Mineralogy Laboratory. Deep Sea Drilling Project, University of California, Riverside. Contribution n74-5, 9991007.

[13] Carretero, I. M., Pozo, M. (2009) Clay and non-clay minerals in the pharmaceutical industry Part I. Excipients and medical applications. Applied Clay Science 46; pp. 73-80.

[14] Chenyi, M. L. V. (2012) Volcanism and hydrochemistry of thermal and mineral springs in the Bambui Sabga area (NorthWest Cameroon). Higher Teachers Training Diploma (DIPES II) in Geology University of Bamenda. 61p.

[15] Cravero, F., Dominguez, E., Iglesias, C. (2001) Genesis and applications of the Cerro Rubio kaolin deposit, Patagonia (Argentina). Appl. Clay Sci. 18, 157-172.

[16] Dário, G. M., Da Silva, G. G., Gonçalves, D. L., Silveira, P., Junior, A. T., Angioletto, E., Bernardin, A. M. (2014) Evaluation of the healing activity of therapeutic clay in rat skin wounds. Mater. Sci. Eng, 43, pp 109-116.

[17] Diko, M., Ekosse, G. I. E. (2014) Soil Ingestion and Associated Health Implications: A Physicochemical and Mineralogical Appraisal of Geophagic Soils from Moko, Cameroon. African Journal of Traditional Complementary and Alternate Medicine. Ethno Med, 8 (1): 83- 88.

[18] Diko, M. L., Siewe, C. N. (2014) Physico- chemistry of geophagic soils ingested to relief nausea and vomiting during pregnancy. African Journal of Traditional Complementary and Alternate Medicine, 11 (3):21-24.

[19] Dill, H. G., Fricke, A., Henning, K. H., Theune, C. H. (1995b) Aluminium Phosphate mineralization from the hypogene La Vanguardia kaolin deposit (Chile). Clay Miner. 30, 249- 256.

[20] Dill, H. G., Bosse, H. R., Henning, K. H., Fricke, A. (1997) Mineralogical and chemical variations in hypogene and supergene kaolin deposits in a mobile fold belt The Central Andes of northwestern Peru. Miner. Depos. 32, 149-163.

[21] Dill, H. G., Bosse, H. R., Kassbohm, J. (2000) Mineralogical and chemical studies of volcanic related argillaceous industrial minerals of the Central America Cordillera (Werstern Salvador). Econ. Geol. 95 (3), 517-538.

[22] Douola Ninla, S. A., Wouatong, A. S. L., Tchounang Kouonang, S., Yerima, B., Njopwouo, D. (2018) Mineralogical and Physico-Chemical Characterization of Clayey Materials of Meka'a (West Cameroon) Preliminary Step for Their Utilization for Human Ingestion. Earth Sciences. 7 (2), 2018, pp. 74-85.

[23] Ekosse, G. I. E., de Jager, L., Ngole, V. (2010) Traditional mining and mineralogy of geophagic clays from Limpopo and Free State provinces, South Africa. African Journal of Biotechnology, 9 (47): 8058 - 8067.

[24] Ekosse, G. (2010) Kaolin Deposits and Occurrences in Africa: Geology, Mineralogy and Utilization. Applied Clay Science 50 (2): 212-236.
[25] Ekosse, G., Jumbam, D. (2010) Geophagic clays: Their mineralogy, chemistry and possible human health effects. African Journal of Biotechnology Vol. 9 (40), pp. 6755- 6767.

[26] Etakah Bate, E., Cheo Suh, E., Cottle, J., Ijunghi Ateh, K., Feudjio Tiabou, A., Anye Nche, L., Bih Che, V., Akumbom Vishiti. (2017) Petrology and geochronology of felsic volcanics in the Sabga area (Bamenda Highlands): implications for age variation along the Cameroon Volcanic Line. Journal of Geosciences, 62, pp 231-246.

[27] Fagel, N., Boski, T., Likhoshway, L., Oberhaensli, H. (2003) Late Quaternary clay mineral record in Central Lake Baikal (Academician Ridge, Siberia). Paleogeography, Paleoclimatology, Paleoecology, 193, 159-179.

[28] Fentaw, M. H., Menguistu, T. (1998) Comparison of Kombelcha and Bombowha kaolin of Ethiopia. Applied Clay Science 13, 149-164.

[29] Finkelman, R. B., Centeno, J. A., Selinus, O. (2005) The Emerging Medical and Geological Association. T. Am. Clin. Climatol. Assoc., 116: 155-165.

[30] Fontes, M. F. P., ldeu, A., Carvalho, J. I. A (2005) Color Attributes and Mineralogical Characteristics, Evaluated by Radiometry of Highly Weathered Tropical Soils. Soil Sci. Soc. Am J., 69: 1162-1172.

[31] Gamiz, E., Delgado Calvo-Flores, G., Parraga, J., Delgado Calvo-Flores, R. (1989) Ann. pharmaceutiques française, pp 47,33 .

[32] Grigsby, R. K., Thyer, B. A., Waller, R. J., Johnston, G. A. (1999) Chalk eating in middle Georgia: a culture-bound syndrome of pica? Southern Med. J., 92: 190-192.

[33] Hajjaji, M., Kacim, S., Boulmane, M. (2001) Mineralogy and firing characteristics of clay from the valley of Ourika (Morocco). Applied Clay Science, 21, 203-212.

[34] Harvey, C. C., Murray, H. H. (1997) Industrial clays in the 21st century: a perspective of exploration, technology and utilization. Appl. Clay Sci. 11, 285-310.

[35] Höllriegel, V., Greiter, M., Giussani, A., Gerstman, U., Michalke, B., Roth, P., Oeh, U. (2007) Observation of changes in urinary excretion of thorium in humans following ingestion of a therapeutic soil. J. Environ. Radioactiv, 95: 149-160.

[36] Hunter, J. M., De Kleine, R. (1984) Geophagy in Central America. Geogr. Rev., 74: 157-169.

[37] Inoue, A. (1995) Formation of clay minerals in hydrothermal environment. In: Velde, B. (Ed.), Origin and Mineralogy of Clays: Clays and the Environment. Springer, Berlin, pp. 268-329.

[38] IARC. (1997) Silica. IARC Monographs on the Evaluation of Carcinogenic Risks to Humans, IARC Scientific Publications, Lyon, France, 41 pp.

[39] Juliana da Silva, F., Jonathan Parisotto, P., Valéria Weiss, A., Rosmary Nichele, B., Lucas Bonan, G., Carlos Pérez, B., Venina dos Santos. (2016) Physical and chemical characterization and method for the decontamination of clays for application in cosmetics. Appl. Clay Sci, p 8.

[40] Kamgang, P., Njonfang, E., Chazot, G., Tchoua, F. (2007) Géochimie et géochronologie des laves des monts Bamenda (ligne volcanique $\mathrm{du}$ Cameroun). Comptes Rendus Geosciences, 339, 659- 666 . 
[41] Kamgang, P., Njonfang, E., Chazot, G., Tchoua, F. (2008) Geochemistry and geochronology of mafic rocks from Bamenda Mountains (Cameroon): Source composition and crustal contamination along the Cameroon Volcanic Line. Comptes Rendus Geoscience, 340, 850-857.

[42] Kamgang, P., Njonfang, E., Nono, A., Gountié, D. M., Tchoua F. M. (2010) Petrogenesis of a Silicic Magma System: Geochemical Evidence from Bamenda Mountains, NW Cameroon, Cameroon Volcanic Line. Journal of African Earth Sciences, 58, 285-304.

[43] Kenne Kalguem, E. D. (2013) Etude géologique et géotechnique des matériaux de Sabga-Bamessing (région du Nord- Ouest Cameroun): implication dans les risques naturels. Mémoire de Master des Sciences de la Terre de la Faculté des Sciences de l'Université de Dschang. 88p.

[44] Kenne Kalguem, E. D., Wouatong, A. S. L., Njopwouo, D., Ekosse G. I. (2018) Physico-chemical Characterization of Clayey Materials Consumed by Geophagism in Locality of Sabga (North-western Cameroon): Health Implications. International Journal of Applied Science and Technology, 8 (3), pp 57- 68.

[45] Ketcha, J., Gabche, S., Ndi, J., Maguie, A. (2011) Kinetic and equilibrium studies of the adsorption of lead (II) ions from aqueous solution onto two Cameroon clays: Kaolinite and smectite. Journal of Environmental Chemistry and Ecotoxicology Vol. 3 (11), pp. 290-297.

[46] Lopez-Galindo, A., Viseras, C., Cerezo, P. (2007) Compositional, technical and safety specifications of clays to be used as pharmaceutical and cosmetic products. Applied Clay Science 36, 51- 63.

[47] Mache, J. R., Signing, P., Njoya, A., Kunyu, F., Mbey, J. A., Njopwouo, D., Fagel, N. (2013) Smectite clay from the Sabga deposit (Cameroon): mineralogical and physicochemical properties. Clay Minerals, 48, 499-512.

[48] Madejová, J., Komdel, P., Cicel, B. (1994) Infrared study of octahedral site populations in smectites. Clay Minerals, 29, 319-326.

[49] Madejová, J. (2003) FTIR techniques in clay mineral studies. Vibrational Spectroscopy, 31, 1- 10.

[50] Marian, A. N., Mavis, K., Godfred, D., Matt, D. (2016) Heavy metal content and potential health risk of geophagic white clay from the Kumasi Metropolis in Ghana. Toxicology Reports 3; 644-651.

[51] Mascolo N., Summa V., Tateo F. (1999) Characterization of toxic elements in clays for human healing use. Applied Clay Science, 15, pp 491-500.

[52] McDonough, W. F., Sun, S. S. (1995) The composition of the earth. Chemical geology 120, 223-253.

[53] Merabet, D., Belkacemi, H. (2003) Caractérisation minéralogique et chimique du kaolin de Tamazert (Algérie). Ann. Chim. Sci. Mat. 28, 61-83.

[54] Meunier, A., Velde, B., Dudoignon, P., Beaufort, D. (1983) Identification of weathering and hydrothermal alteration in acidic rocks: petrography and mineralogy of clay minerals. Sci. Géol., Mém. 72, 93-99 (Strasbourg).

[55] Meyer, C., Hemley, J. J. (1967) Wall rock alteration. In: Barnes, H. L. (Ed.), Geochemistry of Hydrothermal Ore Deposits, pp. 167-235.
[56] Mitchell, C. J. (1994) Laboratory evaluation of kaolin: a case study from Zambia. In: Whateley M. K. G., Harvey, P. K. (Eds.), Mineral Resource Evaluation II: Methods and Case Histories, Geol Soci. Special Publ., vol. 79, pp. 241247.

[57] Moore, D., Reynolds, J. R. (1997) X-Ray Diffraction and the identification and analysis of clay minerals. Oxford University Press, Oxford, 332p.

[58] Murray, H. H., Keller, W. D. (1993) Kaolin, kaolin and kaolin. In: Murray, H. H., Bondy, W., Harvey, C. (Eds.), Kaolin Genesis and utilization. Special Publ., vol. 1. The Clay Miner. Soci., pp. $1-24$.

[59] Murray, H. H. (2000) Traditional and New Applications for Kaolin, Smectite, and Palygorskite: A General Overview. App. Clay Sci., 17, 5, 207-221.

[60] Ndzie, E. M. C. (2009) Utilisation empirique des argiles brutes dans des pathologies digestives. (Observation de la ville de Dschang). Thèse de doctorat en médecine, $103 \mathrm{p}$.

[61] Ngole, V. M., Ekosse, G. E. (2012) Physico-chemistry, mineralogy, geochemistry and nutrient bioaccessibility of geophagic soils from Eastern Cape, South Africa. Scientific Research and Essays Vol. 7 (12), pp. 1319-1331.

[62] Nguetnkam, J. P. (2004) Les argiles des vertisols et des sols fersiallitiques de l'Extrême Nord Cameroun: Genèse, propriétés cristallographiques et texturales, typologie et applications à la décoloration des huiles végétales. Thèse Doc. D'Etat, Univ. Yaoundé I, 216P.

[63] Njopwouo, D. (1984) Minéralogie et physico-chimie des argiles de Bomkoul et de Balengou (Cameroun). Utilisation dans la polymérisation du styrène et dans le renforcement du caoutchouc naturel. Thèse Doct. D'Etat, Univ. Yaoundé, Cameroun.

[64] Njopwouo, D., Téjiogap, E., Sondag, F., Volkoff, B., Wandji, R. (1998) Caractérisations minéralogiques et chimiques des argiles consommées par géophagisme au Cameroun. Ann. Fac. Sci., Univ. Ydé I, 31 (2), 319-334.

[65] Njoya, A., Nkoumbou, C., Grosbois, C., Njopwouo, D., Njoya, D., Courtin, N. A., Yvon, J., Martin, F. (2006) Genesis of Mayouom kaolin deposit (West Cameroon). Applied Clay Science, 32, pp 125-140.

[66] Nkalih, M. A., 2016. Cartographie et propriétés physicochimiques des argiles de Foumban (Ouest- Cameroun). Thèse Doc. D’Etat, Univ. Yaoundé I, 166P.

[67] Nyakairu, G. W. A., Koebrel, C., Kurzweil, H. (2001) The Buwambo kaolin deposit in central Uganda: mineralogical and chemical composition. Chem. J. 35, 245-256.

[68] Nyakairu, G., Koeberl, C. (2001) Mineralogical and chemical composition and distribution of rare earth elements in clay-rich sediments from central Uganda. Geochemical Journal, Vol. 35, pp. 13- 28.

[69] Ossah, N. H. (1975) Altération des roches volcaniques dans les Monts Bamenda, Cameroun. Géologie, minéralogie et géochimie. Thèse Doct. 3e cycle, Univ. Paris VI, France.

[70] Osredkar, J. (2012) "Copper and zinc, biological role and significance of copper/zinc imbalance," Journal of Clinical Toxicology, vol. 2013. 
[71] Petit, S. (1994) Hétérogénéité et variabilité de la composition chimique des minéraux argileux: à quelle échelle? Discussion de la notion de solution solide. HDR, Univ., Poitiers, France.

[72] Poensin, D., Carpentier, P., Féchoz, C., Gasparini, S. (2003) Effects of mud pack treatment on skin microcirculation. Joint Bone Spine, 70, pp 367-370.

[73] Prudêncio, M. I., Gouvela, M. A., Braga, S. M. A. (1995) REE distribution in present - day and ancient surface environments of basaltic rocks (central Portugal). Clay minerals, 30, 239 248 .

[74] Santos, M. C., Varajão, A. F., Yvon, J. (2004) Genesis of clayey bodies in Quadrilàtero Ferrífero, Minas Gerais, Brazil. Catena 55, 277-291.

[75] Scherz, H., Kirchhoff, E. (2006) "Trace elements in foods: zinc contents of raw foods a comparison of data originating from different geographical regions of the world," Journal of Food Composition and Analysis, vol. 19, pp. 420-433.

[76] Shanker, A., Venkateswarlu, B. (2011) "Chromium: environmental pollution, health effects and mode of action," Encyclopedia of environmental health, pp. 650-659.

[77] Sheppard, S. C. (1998) Geophagy: who eats soil and where do possible contaminants go? Environ. Geol., 33 (2- 3): 109-114.

[78] Soetan, K., Olaiya, C., Oyewole, O. (2010) "The importance of mineral elements for humans, domestic animals and plantsA review," African Journal of Food Science, vol. 4, pp. 200222.

[79] Tassongwa, B., Nkoumbou, C., Njoya, D., Njoya, A., Tchop, J. L., Yvon, J., Njopwouo, D. (2014) Geochemical and Mineralogical Characteristics of the Mayouom Kaolin Deposit, West Cameroon. Earth Science Research, 3 (1), 94 p.

[80] Tassongwa, B., Eba, F., Njoya, D., Numbem, J., Jeudong, N., Nkoumbou, C., Njopwouo, D. (2017) Physico- chemistry and geochemistry of Balengou clay deposit (West Cameroon) with inference to an argillic hydrothermal alteration. Compte Rendu Geoscience 349, pp 212-222.

[81] Todor, N. (1976) Thermal analysis of minerals. ABACUS Press, pp 224-225.

[82] Tonle, I., Ngameni, E., Njopwouo, D., Carteret, C., Walcarius, A. (2003) Functionalization of natural smectite- type clays by grafting with organosilanes: physico-chemical characterization and application to mercury (II) uptake. Chem. Phys., 5, pp 4951-4961.

[83] US Pharmacopeia. (2004) Bentonite, 27. US Pharmacopoeia Convention, Rockville, MD, p. 2826.
[84] US Pharmacopeia. (2004b) Purified bentonite, 27. US Pharmacopoeia Convention Rockville, MD, pp. 2827-2828

[85] USPC (United States Pharmacopoeial Convention). 1990c Bentonite. In: The National Formulary XVII. United States Pharmacopoeial Convention, Rockville, pp. 1902-1903.

[86] USPC (United States Pharmacopoeial Convention). 1990d Bentonite magma. In: The National Formulary XVII. United States Pharmacopoeial Convention, Rockville, p. 1904.

[87] USPC (United States Pharmacopoeial Convention). 1990e Purified bentonite. In: The National Formulary XVII. United States Pharmacopoeial Convention, Rockville, pp. 1903-1904.

[88] USPC (United States Pharmacopoeial Convention). 1990f Magnesium aluminum silicate. In: The National Formulary XVII. United States Pharmacopoeial Convention, Rockville, pp. 1943- 1944.

[89] Viseras, C., Cultrone, G., Cerozo, P., Aguzzi, C., Baschini, M. T., Valles, J., Lopez-Galindo, A. (2006) Characterization of northern Patagonian bentonites for pharmaceutical uses. Applied Clay Science, 31, 272-281.

[90] Wang, Q., Zhao, H., Chen, J., Gu, K., Zhang, Y., Zhu, Y. (2009) "Adverse health effects of lead exposure on children and exploration to internal lead indicator," Science of the Total Environment, vol. 407, pp. 5986-5992.

[91] WHO (World Health Organisation). (2008) "Guidelines for drinking-water quality electronic resource: Incorporating 1st and 2nd addenda, Vol. 1, Recommendations, Third editions".

[92] Williams, L. B., Haydel, S. E. (2010) Evaluation of the medicinal use of clay minerals as antibacterial agents. Int. Geol. Rev., 52 (7-8): 745-770.

[93] Worasith, N., Goodman, B. A., Neampan, J., Jeyachoke, N., Thiravetyan, P. (2011) Characterization of modified kaolin from the Ranong deposit Thailand by XRD, XRF, SEM, FTIR and EPR techniques. Clay Minerals, 46, 539-559.

[94] Wouatong, G. A., Kitagawa, R., Takenos, Tchoua, F. M., Njopwouo, D. (1996) Morphological transformation of Kaolin minerals from granite saprolite in the Western part of Cameroun. Clay Sci. 10 (1), 67-81.

[95] Wouatong, G. A. (1997) Mineralogical study of weathering on the Bana complex, west part of Cameroon. J. Sci. Hiroshima Univ., Ser. C II (1), 1-43.

[96] Young, S. L. (2007) A vile habit ? The potential biological consequences of geophagia, with attention to iron. In: Mac Clancy J, Henry J, Macbeth H. eds. Consuming the Inedible: Neglected Dimensions of Food Choice. Oxford, United Kingdom. 